scheme organiser. Copies of the goal sheets are kept by the trainee, supervisor and scheme organiser.

\section{Evaluation sheet}

There are two evaluation forms, one for the supervisor, the other for the senior registrar. Both cover the same ground and have the following components: assessment, treatment, clinical research, training of other staff, management and organisation, and general ratings. Each section has a number of subheadings where comments can be recorded and a satisfactory/unsatisfactory rating given for each section. These can then be aggregated to give an overall satisfactory/unsatisfactory rating. These are filled in at the midway point and at the end of the placement in the presence of the scheme organiser.

The general feedback from both trainees and supervisors has been favourable so far. Feedback from them has helped modify the content and structure. I would be interested to hear other trainers'/trainees' experiences in this area which is likely to be given fresh impetus by implementation of the Calman Report. References are avallable on request.

JOHN MORGaN, Oxfordshire Learning Disability NHS Trust, Slade House, Horspath Driftway, Headington, Oxford OX3 7JH

\section{A piece of her mind}

Sir: He too was a kind man, a caring GP in an inner city practice. Now the cruel stroke of fate that robbed your psychiatrist of his very self (Psychiatric Bulletin, January 1994, 18, 12) also steals this man's mind with the relentless progression of Alzheimer's syndrome.

He too loved reading, politics, music, nature and good conversation. He too knew at the beginning what was happening and felt humiliated by the diagnosis but tried to live his life with dignity and good humour and keep his feelings to himself. To be a doctor, any doctor, with the diagnosis of Alzheimer's is indeed hard to bear.

This man though had no family apart from his three teenage children and wife who moved straight from bringing up a family to caring for a husband. She has had to give up hope of returning to work, at the mercy of inappropriate and inadequate community care in an illness where needs change constantly, to be mother and father to the children, to forego all social life, to become isolated in the task of caring and to contend with the financial implications of supporting three children through university and beyond, and the daunting prospect of caring for a husband who could live 20 years or more.

It is time for him to be the recipient of the love, care, patience and encouragement that he gave so liberally to others. But, sadly, in the real world it is not there. There is no-one else to share the burden of the disease. Yes, friends and colleagues do assume new and greater importance and their visits, now rare, are treasured. His colleagues were too busy looking after their own patients to spare much time for friendship and when, after five years, they drifted away altogether, embarrassed, bored, helpless, or who knows, afraid of what they saw, fearful that one day they too could fall victim to such devastation. what then?

It is a heartbreaking experience caring for an Alzheimer's sufferer. Rewarding moments become few and far between and that challenge once faced with determination begins to lose its way. When one wife, still in her 40 s, starts to sink under the load, too exhausted to care about how she lives each day, unable to see strength and beauty in any of those seeds and memories planted by a once-loved husband, what happens then? There is no one to pick up the pieces of her shattered life or care for her. There is no light at the end of the long tunnel that is Alzheimer's disease.

ANONYMOUS

\title{
Reunion of RAF psychiatric personnel
}

It is proposed to hold a reunion dinner for all current and former RAF psychiatric personnel with a view to forming a RAF Psychiatric Association. Would all eligible former members please contact F. S. Jones, Unit Manager, Psychiatric Centre, Princess Alexandra's RAF Hospital, Wroughton, Swindon SN4 OQJ, (telephone 0793812291, extension 7243). 